\title{
Forecasting of Operating Cash Flow: Case of the Tunisian
}

\section{Commercial Companies}

\author{
Aymen Telmoudi \\ UR: e-management, système d'information et globalisation e-masig, FSEG de Tunis \\ Campus Universitaire - B.P. 248 - El Manar II - 2092 Tunis, Tunisie \\ Tel: 21-697-650-946Ｅ-mail: aymen.telmoudi@yahoo.fr \\ Hedi Noubbigh \\ Institut des Hautes Etudes Commerciales de Carthage \\ Carthage, Présidence 2016, Tunisie \\ Jameleddine Ziadi \\ UR: e-management, système d'information et globalisation e-masig, FSEG de Tunis \\ Campus Universitaire, B.P. 248, El Manar II, 2092 Tunis, Tunisie
}

\begin{abstract}
This article aims to determine the ability of three different models in terms of forecasting future cash flow. This study was conducted from a representative sample of Tunisian commercial companies. The results introduce that the forecasting model more effective in the context of Tunisia is the one based on the timely debt collection, gross commercial margin, timely flow of stock and timely debt payment. The predictive power of this model was shown at the horizon of one, two and three years. The past cash flow presents also a good predictor of future operating cash flow; but with a lower predictive power compared to that of the elements related to the operating cycle. In the other side, the results show that the model based on past earning is defective in terms of forecasting future cash flow.
\end{abstract}

Keywords: Operating cash flow, Operating cycle, Earnings, Forecasting, Commercial companies

\section{Introduction}

Considering the importance and the utility of information based on operating cash flow, much research was evoked in order to forecast this variable. In this regard, it is to remember that the FASB (Financial Accounting Standard Board) affirmed in 1978 that the last earnings provide a better base for the estimate of future operating cash flow than the data based on last cash flows. This assertion, on the one hand, was cancelled by several studies such as Finger (1994), Krishnan and Largay (1997), Barth and al.. (2001), Hussain and al. Attar (2003) Farshadfar and al. (2008)... and on the other hand, confirmed by other studies such as Rayburn (1986), Murdoch and Krause (1989, 1990), Dechow (1994), Dechow and al.. (1998)... Therefore, we can conclude that the former studies could not judge with certainty in favour of any explanatory variable (cash-flow, earnings, accrual...), to forecast the future operating cash flow.

Dechow et al. (1998), recommended that the cash-flows forecasts exactitude is a function of the operating cycle characteristics. This last, in its turn, is often a function of the several elements such as, the timely debt collection, the timely debt payment, the timely flow of stock, the gross commercial margin, the variation of turnover... For this, Telmoudi et al. (2010) have tried to put this variable in relation with the factors related to the operating cycle. Their work demonstrated the importance of these factors on the behavior of operating cash flows. They established a causal relationship between operating cash flows and four explanatory variables namely the timely debt collection, the gross commercial margin, the timely flow of stock and the timely debt payment. These results were obtained from a significant sample of Tunisian commercial companies.

The objective of this paper is to identify explanatory variables most efficient in terms of forecasting future cash flows. The first model is based on the timely debt collection, the gross commercial margin, the timely flow of 
stock and the timely debt payment, the second on past earnigs and the third on past operating cash flows. This study was conducted from a representative sample of Tunisian commercial companies.

The organisation of this work is as a follows: In section 2, we present a general review of literature relating to forecasting operating cash flows. The third section is devoted to the formulation of hypotheses. The fourth describes the methodology. Results and interpretations will be presented in the fifth section.

\section{Review of the literature}

Having the objective of forecasting future cash flow, a lot of studies have been conducted by several researchers in several different economic. These earlier studies focused on prediction of future cash flows have not shown any superiority of cash flows at the expense of accounting results or vice versa.

These studies were initiated following the assertion of the FASB (Financial Accounting Standards Board) in the statement of "objectives annual accounts published by companies" made in 1978. The FASB said in the statement that past accounting results provide a better basis for estimating future cash flows that the amount of cash flows in the past. The results of these studies have not confirmed the position of the FASB as several researchers have shown that cash flows are the most useful basic and most important for predicting future cash flows.

In this regard Bowen et al. (1986) studied the various measures of cash flows, and their ability to predict future cash flows. The results showed that the current operating cash flows better predict future cash flows from operating current accounting results. Similarly, the study by Finger (1994) aimed to compare the ability of operational cash flows from operations to accounting results in terms of respective abilities to predict future cash flows. His study has focused on several U.S. firms from 1935 until 1987 and the results showed that cash flows have an earlier predictor of future cash flows over the accounting results of operations. This superiority was also confirmed by this study to the horizon one and two years. However, over longer horizons, the variable operating cash flow has almost the same significance and the same predictive ability. Therefore we can conclude that the horizon of the forecast is a determinant of the quality prediction.

The study by Krishnan and Largay (1997) had a huge contribution on the relevance of the direct method of calculating cash flow towards the indirect method. According to this study, the direct method of determining cash flows, based on receipts and disbursements, is more relevant in predicting future cash flows towards accounting results. The merit of this direct method has been demonstrated through the study of Sidhu and Clinch (2000). On the one hand, this study showed that the components of operating cash flows provided by the direct method have additional predictive power to those calculated using the indirect method. On the other hand, this study also showed that these components provide a higher predictive power than the aggregate cash flows in predicting future cash flows.

The research of Barth et al. (2001) showed that the variable cash flow from operations remains the most relevant variable in the prediction of future cash flows. Moreover each component of accruals reflects relevant information on future cash flows. This study was focused on a large number of U.S. firms over a period from 1987 to 1996 .

The study of Hussain and Al Attar (2004) confirmed the results generated by Barth et al (2001). This study has presented an extension of the work of Barth et al. (2001). It was conducted on a sample containing British firms listed on the London Stock Exchange (LSE) over a period from 1991 to 2000.

The study of Farshadfar et al. (2008) also showed the superiority of the operating cash flow towards the accounting results in predicting future cash flows. This research was conducted in Australia and it has examined 323 listed companies (The Australian Stock Exchange) between 1992 and 2004. In addition, the study showed that the predictive power of operating cash flow increased significantly with the size of the company. However, the superiority of operating cash flows in terms of predicting future cash flows is also found in small and medium enterprises.

These studies have provided evidence of the importance and relevance of cash flows from operations towards the accounting results in terms of forecasting future cash flows. But it should be noted that under the same objective, several other studies have shown the opposite namely, the superiority of accounting results in forecasts of future cash flows and that in accordance with FASB statement. Among these studies, particularly we recall the studies of Greenberg et al. (1986), Rayburn (1986), Murdoch and Krause (1989, 1990), Dechow (1994), Dechow et al. (1998).

Dechow et al. (1998) showed that the operating cash flows are better provided by the accounting results by using two different methodologies. This research has advanced a predictive model based on accounting results. This 
model was criticized by Barth et al. (2001) in stating that this model was based on assumptions suffering from serious limitations.

The importance and usefulness of the elements related to the operating cycle in predicting future cash flows has been demonstrated through the information content and forecast continued in accruals. Indeed, the accruals are the products or charges that did not generate cash flows during the period for which they were recorded. These accruals include depreciation, amortization and provisions, revenue and expenses to stabilize and the change in working capital needs, which includes changes in inventories, the change in accounts receivable, and changes in debt.

In order to predict future cash flows. Subramanyem (1996) has shown that accruals are informative about the value of firms and therefore, they present a superior measure of enterprise performance than cash flows because they reduce the time and problems of disparity in the measure of cash flow. The study of Subramanyem (1996) tested single and multiple regressions using a sample of 211,350 observations. It has also shown that accruals are relevant in terms of forecasting future cash flows discounted.

As part of their study to show the superiority of earnings relative to operating cash flows in predicting future cash flows, Dechow et al. (1998) showed that earnings are the best predictors of future cash flows and whether this alone or combined with cash flow. The superiority of the predictive power of accounting results is due to accruals that are the difference between earnings and cash flows from operations (earnings $=$ cash flow + accounting Accruals). These accruals include among others the change in operating items.

The study of Barth et al. (2001) has highlighted the role of accruals in predicting future cash flows. This study demonstrated in a first step that the simple regression method based on operating cash flows provides the best basis for predicting future cash flows than those based on earnings. In a second step this study has shown that predictions of cash flows by the accounting results are improving by the decomposition of the latter in operating cash flows and accruals totals. This advantage improves explanatory power by decomposing total accruals into their main components namely:

- variation in accounts receivable,

- variation in accounts payable,

- variation in inventories,

- variation in accounts receivable,

- variation of debts,

- depreciation and provisions.

Thus, the variable cash flow from operations remains the most relevant variable in this model and each component of accruals reflects a significant and relevant information on future cash flows.

The study of Hussain and Al-Attar (2004) examined the behavior of aggregated and disaggregated accruals in predicting future cash flows. This study also showed that the disintegration of the earning in cash flow and accrual aggregate improves the predictive power of future cash flows. These findings are confirmed in horizon of one, two and three years. Similarly, the disintegration of the aggregate accrual into its components further improves the predictive power of cash flow and this is in horizon of one, two and three years. These results are significant and they are also confirmed by several statistical tests are not used by Barth et al. (2001).

These results confirm several previous studies in the U.S. and the United Kingdom as Guay and Sidhu (2001), Board et al. (1989); Mc Leay et al. (1997) despite the different methodologies adopted. Moreover, these results are not in agreement with other previous results such as Rayburn (1986), Dechow (1994), Dechow et al. (1998).

Through these various previous studies, it is difficult to conclude in favour of cash flows, earnings or accruals to forecast operating cash flows. Besides, Beth (1993) found that neither earnings nor cash flows of operations constitute a good basis for forecasting future cash flows. This diversity of results leads us to conduct research efforts to better predict the variable cash flow from operations.

We will try to show the importance of elements related to the operating cycle in terms of forecasting future cash flows. It should be noted that the study of Telmoudi et al. (2010) showed the importance of these operating cycle elements for the determination of cash flows. This study focused on a representative sample of Tunisian commercial companies. 


\section{Formulation of hypotheses}

To explain cash flow from operations, Telmoudi and al. (2010) showed that variables, timely debt collection, timely debt payment, timely flow of stock and gross commercial margin have a significant and important explanatory power. In this article we will test the ability of these variables related to the operating cycle in terms of predicting future cash flows in the Tunisian context:

Hypothesis (H 1): Future operating cash flow varies depending on timely debt collection, timely debt payment, timely flow of stock and gross commercial margin

Several researchers have shown the relevance of earnings in terms of predicting future cash flows, such as studies Rayburn (1986), Dechow (1994), Dechow et al. (1998). That is why we will also test the ability of this variable in terms of forecasting future cash flows in the Tunisian context:

Hypothesis (H 2): Future operating cash flow varies depending on earnings

It is also noteworthy that several previous studies have demonstrated the relevance of data based on operating cash flows in terms of forecasting future cash flows, such as studies of Bowen et al. (1986); Finger (1994), Barth et al. (2001), Hussain and Al Attar (2004) and Farshadfar et al. (2008). For this reason, we will also test their predictive power in the Tunisian context:

Hypothesis (H 3): Future operating cash flow varies depending on past operating cash flow

\section{Methodology}

\subsection{Definition and measurement of the variables}

\subsubsection{Operating cash-flow: OCF (dependent variable)}

The operating cash-flow was generally approximated by the earning withdrawn depreciations and provisions: capacity of self-financing. This traditional definition of operating cash flow, used in several studies of bankruptcy and stock exchange market (Beaver (1966), Ball and Browen (1968)), was criticized by more recent studies which called upon more elaborate measurements of cash-flow. These studies referred to the modes of calculation recommended by the SFAS $n^{\circ} 95$ to measure the variable cash-flow (Livnat and Zarwin (1991), Dechow and al. (1998), Fédhila (1998)). Two methods were planned for the determination of operating cash-flow:

Indirect method: (as inspired by the SFAS $n^{\circ} 95$ (1987)):

Operating cash flow $=$ Earnings

$$
\begin{aligned}
& \text { + Depreciations and provisions } \\
& \text { + Adjustment for: }
\end{aligned}
$$

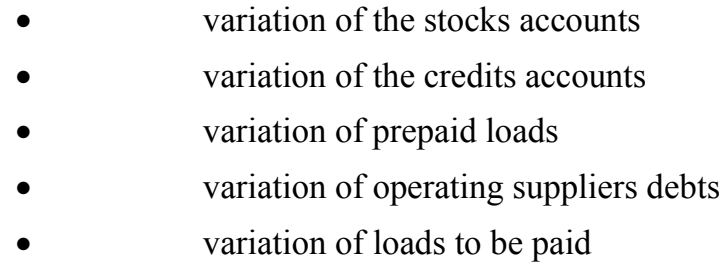

- $\quad$ Direct method: (as inspired by the SFAS n ${ }^{\circ} 95$ )

Operating cash flow $=$ cash inflow received from the customers - cash outflow liquidated to the suppliers - cash outflow of operating loads

Epstein and Pava (1992) affirm that this method is the simplest and most objective. Also, it clearly reflects the independence of operating cash flows from any notion tainted by the effect of the evaluation accounting methods. But within the framework of our research, we will choose the two methods according to the layout grid of the cash flow state chosen by the company.

\subsubsection{Timely debt collection: TDC (explanatory variable)}

This variable is expressed in a number of days.

Timely debt collection $=\frac{\text { credits and attached counts }}{\text { Turnover }(\text { All Taxes Included })} \times 360$ days

4.1.3 Timely debt payment: TDP (explanatory variable)

This variable is also expressed in a number of days. 


$$
\text { Timely debt payment }=\frac{\text { suppliers } \text { and attached counts }}{\text { Purchases }(\text { All Taxes Included })} \times 360 \text { days }-
$$

\subsubsection{Timely flow of stock: TFS (explanatory variable)}

This time is calculated as follows:

Timely flow of stock $=\frac{\text { stock }(\text { selling price excluding tax })}{\text { Turnover }(\text { excluding tax })} \times 360$ days

4.1.5 Gross commercial margin: GCM (explanatory variable)

The variable gross commercial margin is calculated according to the ratio:

$$
\text { Gross commercial } \text { margin }=\frac{\text { selling price }(\text { All taxes included })-\text { purchase price }(\text { excluding tax })}{\text { selling price }(\text { All taxes included })} \times 100
$$

\subsubsection{Earnings: E (explanatory variable)}

Dechow (1994), De Angelo, De Angelo and Skinner (1992) showed through their studies that this variable is the best preacher of operating cash flow to the detriment of the former cash flow, although they took account of the elements except exploitation.

If the loads and the products are presented according to their sources or destinations (method of reference), the earnings would be given as follows:

Earnings $=$ Income - Cost of the sales + other products from operating activities - (Expenses of distribution + Administrative expenses + other loads from operating activities).

If the loads and the products are classified according to their nature (authorized method), the earnings are equal to the difference between the operating products and the operating loads:

Earnings $=$ operating products - operating loads

\subsection{Selection of the sample}

Our sample is composed of 52 Tunisian companies belonging to the commercial sector. This choice was adopted considering the existing differences between this sector and the others, on the level of the variables which constitute the models of our study. In the same way the banks, the insurance companies, the leasing companies and the financial investment companies are excluded from the sample considering the specificity of the countable and economic regulations to which they are subjected.

\subsection{Collection of data}

Data were collected from the Financial Market Council Tunisia (FMC): The Official Bulletin of the FMC and prospectuses issued by companies using public offering.

Information used in order to carry out the study is the financial statement composed of the balance sheet, state of result, state of cash flow and notes to the financial statements. The period of study is spread out from 1998 to 2008 . However, the number of the companies varies from one year to another in such a way that certain companies were not represented in the sample for each year. Thus it is a no-rolled panel. The table (1) summarizes information concerning dissolved companies studied

\subsection{Econometric models applied}

In the case of a modeling data panel, three procedures are used to estimate coefficients:

- Procedure of Ordinary Least Squares (OLS): this procedure of regression is generally used for individual data (cross section) or temporal data. It can be also used for panel data. But for this type of the data it presents a bad way of doing things, it ignores the double dimension.

- The Fixed Effect Model: this model of regression is frequently applied for panel data. It takes into account the heterogeneity of the companies presented in the sample.

- The Random Effect model: this regression model is often applied to panel data. This model takes into account any risk of heterogeneity influence in the behaviour by breaking up the error into two components: $\varepsilon_{\text {it }}=$ $\mu_{\mathrm{I}}+\mathrm{v}_{\text {it }}$

with:

- $\mu_{\mathrm{i}}$ random variable specific to the company, it takes into account any risk of heterogeneity influence in the behavior, it is invariable over time.

- $\mathrm{v}_{\mathrm{it}}$ : new term of error. 
It is noted that the last two models take into account heterogeneity between the companies of the sample. But, before thinking of taking into account heterogeneity, it was first of all necessary to be ensured of the need for introducing a heterogeneous dimension into the estimate.

\section{Constants homogeneity test:}

When considering a sample panel data, the first thing to check is the homogeneous or heterogeneous specification of process data generator. The test is formulated in the following way:

$\mathrm{H}_{0}: \beta_{\mathrm{i}}=\beta$;

$\mathrm{H}_{1}: \beta_{\mathrm{i}} \neq \beta$

The acceptance of $\mathrm{H}_{0}$ confirms the absence of a specific effect. Hence all firms are assumed homogeneous. Contrary to that the confirmation of $\mathrm{H}_{1}$ provides evidence of the presence of heterogeneity among firms. It is a test of Fisher with N-1 and N(T-1)-k degrees of freedom.

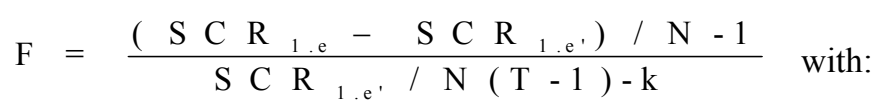

$\mathrm{SCR}_{1 . \mathrm{e}}$ : the residues squares sum of individual effect model;

$\mathrm{SCR}_{1 . \mathrm{e}^{\prime}}$ : the residues squares sum of common effect model;

$\mathrm{N}$ : number of companies

$\mathrm{T}$ : period of observation

$\mathrm{k}$ : number of explanatory variables.

If calculated $\mathrm{F}$ is lower than tabulated $\mathrm{F}$ ( $\mathrm{p}$-values $<0.05$ ), $\mathrm{H}_{0}$ is rejected. Otherwise, $\mathrm{H}_{0}$ is accepted. Once the null hypothesis is rejected (so we must take into account the heterogeneity). At this level we have to choose between the fixed effect model and the random effect model.

\section{Hausman test.}

The choice between the fixed effect model and the random effect model is carried out through the test of Hausman. In general, the random effect model is the best when the hypothesis posed on $\mu_{\mathrm{I}}$ and $\mathrm{v}$ it is respected strictly. This model goes bad when the narrower term $\mu_{\mathrm{i}}$ is correlated with the explanatory variables. Thus our choice will be such as:

- If there is not correlation between $\mu_{\mathrm{i}}$ and explanatory variables $\left(\operatorname{cov}\left(\mathrm{x}_{\mathrm{i}}, \mu_{\mathrm{i}}\right)=0\right)$, we choose (random effect model).

- If not, the fixed effects model is chosen.

So, we test the two following hypothesis:

$\mathrm{H}_{0}: \operatorname{cov}\left(\mathrm{x}_{\mathrm{it}}, \mu_{\mathrm{i}}\right)=0$

$\mathrm{H}_{1}$ : $\operatorname{cov}\left(\mathrm{x}_{\mathrm{it}}, \mu_{\mathrm{i}}\right) \neq 0$

The regression models are as a follows:

Forecast models at the horizon of one year:

Model (1): $\mathrm{OCF}_{\mathrm{it}}=\beta_{0}+\beta_{1} \mathrm{TDC}_{\mathrm{it}-1}+\beta_{2} \mathrm{GCM}_{\mathrm{it}-1}+\beta_{3} \mathrm{TDP}_{\mathrm{it}-1}+\beta_{4} \mathrm{TFS}_{\mathrm{it}-1}+\varepsilon_{\mathrm{it}-\mathrm{1}}$

Model (2): $\mathrm{OCF}_{\mathrm{it}}=\beta_{0}+\beta_{1} \mathrm{E}_{\mathrm{it}-1}+\varepsilon_{\mathrm{it}-1}$,

Model (3): $\mathrm{OCF}_{\mathrm{it}}=\beta_{0}+\beta_{1} \mathrm{CF}_{\mathrm{it}-1}+\varepsilon_{\mathrm{it}-1}$,

Where $\varepsilon_{\text {it-1 }}$ it means an error term.

Forecast models at the horizon of two year:

Model (1a): $\mathrm{OCF}_{\mathrm{it}}=\beta_{0}+\beta_{1} \mathrm{TDC}_{\mathrm{it}-2}+\beta_{2} \mathrm{GCM}_{\mathrm{it}-2}+\beta_{3} \mathrm{TDP}_{\mathrm{it}-2}+\beta_{4} \mathrm{TFS}_{\mathrm{it}-2}+\varepsilon_{\mathrm{it}-2}$

Model (2a): $\mathrm{OCF}_{\mathrm{it}}=\beta_{0}+\beta_{1} \mathrm{E}_{\mathrm{it}-2}+\varepsilon_{\mathrm{it}-2}$,

Model (3a): $\mathrm{OCF}_{\mathrm{it}}=\beta_{0}+\beta_{1} \mathrm{CF}_{\mathrm{it}-2}+\varepsilon_{\mathrm{it}-2}$,

Where $\varepsilon_{\text {it-2 }}$ it means an error term.

Forecast models at the horizon of three year:

Model (1b): $\mathrm{OCF}_{\mathrm{it}}=\beta_{0}+\beta_{1} \mathrm{TDC}_{\mathrm{it}-3}+\beta_{2} \mathrm{GCM}_{\mathrm{it}-3}+\beta_{3} \mathrm{TDP}_{\mathrm{it}-3}+\beta_{4} \mathrm{TFS}_{\mathrm{it}-3}+\varepsilon_{\mathrm{it}-3}$ 
Model (2b): $\mathrm{OCF}_{\mathrm{it}}=\beta_{0}+\beta_{1} \mathrm{E}_{\mathrm{it}-3}+\varepsilon_{\mathrm{it}-3}$,

Model (3b): $\mathrm{OCF}_{\mathrm{it}}=\beta_{0}+\beta_{1} \mathrm{CF}_{\mathrm{it}-3}+\varepsilon_{\mathrm{it}-3}$,

Where $\varepsilon_{\text {it-3 }}$ it means an error term.

For these models we will estimate $\beta_{0}, \beta_{1}, \beta_{2}, \beta_{3}$ and $\beta_{4}$. Subsequently we will test the significance of each factor through the Student test and calculate the explanatory power of each model $\left(R^{2}\right.$ and adjusted $\left.R^{2}\right)$

\section{Interpretations of results and statistical tests}

We will interpret so the different results obtained by accepted statistical tests applied.

5.1 Estimation results of forecasting models at the horizon of one year

Model (1): $\mathrm{OCF}_{\mathrm{it}}=\beta_{0}+\beta_{1} \mathrm{TDC}_{\mathrm{it}-1}+\beta_{2} \mathrm{GCM}_{\mathrm{it}-1}+\beta_{3} \mathrm{TDP}_{\mathrm{it}-1}+\beta_{4} \mathrm{TFS}_{\mathrm{it}-1}+\varepsilon_{\mathrm{it}-1}$

Model (2): $\mathrm{OCF}_{\mathrm{it}}=\beta_{0}+\beta_{1} \mathrm{E}_{\mathrm{it}-1}+\varepsilon_{\mathrm{it}-1}$,

Model (3): $\mathrm{OCF}_{\mathrm{it}}=\beta_{0}+\beta_{1} \mathrm{CF}_{\mathrm{it}-1}+\varepsilon_{\mathrm{it}-1}$,

Where $\varepsilon_{\mathrm{it}-1}$ it means an error term.

For all three models forecast at the horizon of one year, the results of homogeneity test constants show that it is obligatory to take into account the heterogeneity between firms because the null hypothesis is rejected in the three models. All p-values are below 5\%. It is therefore necessary to choose between fixed effect model and random effect model. This choice is made by applying the test of Hausman. The results of this test are summarized in table (2).

The Hausman test results show that random effect model will be selected for the estimation of three models (1), (2) and (3). The value of p-values is greater than $5 \%$ for the three models. So there is no correlation between explanatory variables and firm-specific effects.

Table (3) provides the estimation results of the first three forecasting models at the horizon of one year.

We note first that the number of observations is 360 observations. For each company, we ignored the first year because we don't have the information of the year ( $t-1)$. From table (3) showing the estimation results of forecasting dependent variable OCF at the horizon of one year, we can see that the models (1) and (3) have, each, high predictive power. By cons, results show that the model (2) is characterized by a relatively low predictive power. For model (1), we recall that this model is based on four variables namely timely debt collection, gross commercial margin timely flow of stock and timely debt payment. These variables have already shown considerable effectiveness in determining operating cash flow (Telmoudi and al. (2010)). This time, based on a sample of Tunisian firms, these variables have shown, once again, their effectiveness in predicting future operating cash flows. Statistically, the model (1) has coefficients $\beta$ i significant at $1 \%$. The predictive power of this model is $72.40 \%$. These results confirm the importance of elements related to the operating cycle in forecasting future operating cash flows.

Model (3), based on past cash flows, has also shown considerable effectiveness in terms of forecasting future cash flows at the horizon of one year. The predictive power of this model exceeds $44 \%$ and the coefficient $\beta 1$ is significant at $1 \%(\mathrm{t}$-statistic $=3.359)$. These results obtained in the context of Tunisia are in confirmation with several earlier studies in the United States, Great Britain and New Zealand as the work of Barth et al. (2001), Hussain and Al Attar (2004) and Farshadfar et al. (2008). But these results, partly, contradict the assertion of the FASB in 1978, since the U.S. accounting body, stated that the future operating cash flows are better predicted by the earnings.

The estimation results of model (2), applied on a representative sample of Tunisian firms, totally contradict the assertion of FASB in 1978. The explanatory variable, earning, showed a deficiency in terms of predicting future operating cash flow. This model has a relatively low predictive power not exceeding $11 \%$. Similarly, the $t$ test shows that the $\beta 1$ coefficient of the variable earning was not significant $(t=1.732)$. Thus, it seems clear superiority of data based on cash flows relative to the data based on the accounting results in terms of predicting future operating cash flows.

However, the results show that the model (1), based on elements related to the operating cycle, is more relevant to predicting the dependent variable operating cash flow. Hence, we can conclude that the predictive power of the elements related to the operating cycle, namely timely debt collection, gross commercial margin, timely flow of stock and timely debt payment, is more important compared to operating cash flow and earning. 
The model that predicts, more significantly, the cash flow from operations at the horizon of one year, with the highest predictive power is the model (1):

$$
\mathrm{OCF}_{\mathrm{it}}=\beta_{0}+\beta_{1} \mathrm{TDC}_{\mathrm{it}-1}+\beta_{2} \mathrm{GCM}_{\mathrm{it}-1}+\beta_{3} \mathrm{TDP}_{\mathrm{it}-1}+\beta_{4} \mathrm{TFS}_{\mathrm{it}-1}+\varepsilon_{\mathrm{it}-1}
$$

Analytically, this model is written as follows:

$$
\mathrm{OCF}_{\mathrm{it}}=-22.798-0.512 \mathrm{TDC}_{\mathrm{it}-1}+1.919 \mathrm{GCM}_{\mathrm{it}-1}+0.231 \mathrm{TDP}_{\mathrm{it}-1}-0.104 \mathrm{TFS}_{\mathrm{it}-1}
$$

\subsection{Estimation results of forecasting models at the horizon of two years}

Model (1a): $\mathrm{OCF}_{\mathrm{it}}=\beta_{0}+\beta_{1} \mathrm{TDC}_{\mathrm{it}-2}+\beta_{2} \mathrm{GCM}_{\mathrm{it}-2}+\beta_{3} \mathrm{TDP}_{\mathrm{it}-2}+\beta_{4} \mathrm{TFS}_{\mathrm{it}-2}+\varepsilon_{\mathrm{it}-2}$

Model (2a): $\mathrm{OCF}_{\mathrm{it}}=\beta_{0}+\beta_{1} \mathrm{E}_{\mathrm{it}-2}+\varepsilon_{\mathrm{it}-2}$,

Model (3a): $\mathrm{OCF}_{\mathrm{it}}=\beta_{0}+\beta_{1} \mathrm{CF}_{\mathrm{it}-2}+\varepsilon_{\mathrm{it}-2}$,

Where $\varepsilon_{\text {it-2 }}$ it means an error term.

For all three models forecast at the horizon of two years, the results of homogeneity test constants show that it is obligatory to take into account the heterogeneity between firms because the null hypothesis is rejected in the three models. All p-values are below 5\%. So the Ordinary Least Squares procedure is not effective in estimating our models. We must therefore proceed to choose between the fixed effect model and the random effect model. This item is recommended by the Hausman test. The results of this test are summarized in table (4). The Hausman test results show that random effect model will be selected for the estimation of three models (1a), (2a) and (3a). The value of $p$-values is greater than $5 \%$ for the three models. So there is no correlation between explanatory variables and firm-specific effects.

Table (5) provides the estimation results of the three forecasting models at the horizon of two years.

From this table we can see that this empirical study was conducted on a sample containing 308 observations. It is, in fact, an estimate of predictive models at the horizon of two years. Each firm is observed from the third year. So in order to estimate the dependent variable operating cash flow of each company at the horizon of two years, we must eliminate the data for this variable during the first and second year. Similarly, data from two years of each firm, referring to the explanatory variables aren't; in turn, used in the estimation of these models.

The results concerning the estimation of forecasting models at the horizon of two years show, once again, the robustness of the elements related to the operating cycle in terms of forecasting future cash flows. We can notice that the variables timely debt collection, gross commercial margin, timely flow of stock and timely debt payment, are so important predictors of the variable operating cash flow from at the horizon of two years. However, the predictive power of these explanatory variables (Model 1a) marked a decrease from that provided by the model (1) from $72.4 \%$ to $60.22 \%$. However, this decrease can be explained by two reasons. On the one hand the number of observations was reduced from 360 observations to 308 observations. On the other hand the forecast horizon is important in predictive ability. The latter decreases with as the forecast horizon increases.

The model (1a) has, therefore, an important predictive power above $60 \%$. In addition, results show that the coefficients of the explanatory variables $\beta 1, \beta 2, \beta 3$ and $\beta 4$ relating to timely debt collection, gross commercial margin, timely flow of stock and timely debt payment are significant at the $1 \%$ with t-statistics which are respectively 5.866, 5.438, 4.761 and 3.104.

The results of regression model (3a) based on cash flows earlier, show that this model has a predictive power that exceeds $38 \%$. This proves that the past cash flows are also a good basis for predicting future operating cash flows even at the horizon of two years. The coefficient $\beta 1$ is significant at $1 \%$ with a value of $t$-statistic that rises to 3.02 .

The results also show that the model (2a) based on the variable, earning, doesn't present a significant predictive ability of our dependent variable future operating cash flow. We find that the predictive power is so low $\left(\mathrm{R}^{2}=\right.$ $6.26 \%$ ) and the coefficient $\beta 1$ is not significant. This proves once again that earning is a poor preacher's cash flow from operations in the Tunisian context even at the horizon of two years.

In general, the estimation results of forecasting models at the horizon of two years show the superiority of data based on elements related to the operating cycle compared to data based on past cash flows and earnings.

In the context of Tunisia, the model that forecasts, most significantly, the cash flow from operations, at the horizon of two years, with the highest predictive power is the model (1a):

$\mathrm{OCF}_{\mathrm{it}}=\beta_{0}+\beta_{1} \mathrm{TDC}_{\mathrm{it}-2}+\beta_{2} \mathrm{GCM}_{\mathrm{it}-2}+\beta_{3} \mathrm{TDP}_{\mathrm{it}-2}+\beta_{4} \mathrm{TFS}_{\mathrm{it}-2}+\varepsilon_{\mathrm{it}-2}$

Analytically, this model is written as follows: 
$\mathrm{OCF}_{\mathrm{it}}=-21.931-0.504 \mathrm{TDC}_{\mathrm{it}-2}+1.896 \mathrm{GCM}_{\mathrm{it}-2}+0.223 \mathrm{TDP}_{\mathrm{it}-2}-0.101 \mathrm{TFS}_{\mathrm{it}-2}$

\subsection{Estimation results of forecasting models at the horizon of three years}

Model (1b): $\mathrm{OCF}_{\mathrm{it}}=\beta_{0}+\beta_{1} \mathrm{TDC}_{\mathrm{it}-3}+\beta_{2} \mathrm{GCM}_{\mathrm{it}-3}+\beta_{3} \mathrm{TDP}_{\mathrm{it}-3}+\beta_{4} \mathrm{TFS}_{\mathrm{it}-3}+\varepsilon_{\mathrm{it}-3}$

Model (2b): $\mathrm{OCF}_{\mathrm{it}}=\beta_{0}+\beta_{1} \mathrm{E}_{\mathrm{it}-3}+\varepsilon_{\mathrm{it}-3}$,

Model (3b): $\mathrm{OCF}_{\mathrm{it}}=\beta_{0}+\beta_{1} \mathrm{CF}_{\mathrm{it}-3}+\varepsilon_{\mathrm{it}-3}$,

Where $\varepsilon_{\text {it-3 }}$ it means an error term.

For all three models forecast at the horizon of three years, the results of homogeneity test constants show that it is obligatory to take into account the heterogeneity between firms because the null hypothesis is rejected in the three models. All p-values are below 5\%. So the Ordinary Least Squares procedure is not effective in estimating our models. We must therefore proceed to choose between the fixed effect model and the random effect model. This task is performed by the Hausman test. The results of this test are summarized in table (6). The Hausman test results show that random effect model will be selected for the estimation of three models (1b), (2b) and (3b). The value of $\mathrm{p}$-values is greater than $5 \%$ for the three models.

Table (7) provides the estimation results of the three forecasting models at the horizon of three years.

This table (7) presents the estimation results of forecasting models, at the horizon of three years. These results were obtained after a multiple regression on a sample of 52 commercial Tunisian companies and 256 observations. The number of observations is again reduced to 52 observations because it is the forecast horizon is three years. Each company was deprived of three observations. For the dependent variable operating cash flow, we considered this variable data from the fourth year. Therefore, data pertaining to the explanatory variables haven't been operated for the last three years, for each company.

The results show that even at the horizon of three years, the elements related to the operating cycle are, again, a good foundation in terms of predicting future cash flows. Model (1b) has an important predictor, which is $46.22 \%$. We also note that the coefficients of variables timely debt collection, gross commercial margin, timely flow of stock and timely debt payment are significant at $1 \%$. Moreover, the Wald $\chi 2$-test is significant at the $1 \%$ (22.14). These results demonstrate the usefulness and importance of elements related to the operating cycle in predicting future cash flow. This model retains its strength even at the horizon of three years of forecast. This shows that managers must take into account the elements of exploitation, to ensure positive cash flows that can be invested in working capital.

The results also show that the past cash flows provide information also significantly on the generation of future cash flows at the horizon of three years. Although the predictive power was reduced to $28.18 \%$, we find that the coefficient of explanatory variable operating cash flow at $\mathrm{t}-3$ is still significant at $1 \%$ (model $3 \mathrm{~b}$ ). These results are consistent with the results already obtained at the horizon of one year and two years. These results also support the work of Barth et al. (2001) in the American context and work of Hussain and Al-Attar (2004) in the British context.

For the data based on operating results (model 2b), we can be seen that the estimation results of the forecasting model of future cash flows at the horizon of three years, clearly shows the ineffectiveness of such data. The predictive power of earning don't exceed 3.64\%, similarly, the coefficient estimate $\beta 1$ is not significant $(\mathrm{t}=$ 0243). These results contradict, again, the position of FASB in 1978.

In the Tunisian context, the model that forecasts, most significantly, the cash flow from operations, at the horizon of three years, with the highest predictive power is the model (1b):

$\mathrm{OCF}_{\text {it }}=\beta_{0}+\beta_{1} \mathrm{TDC}_{\mathrm{it}-3}+\beta_{2} \mathrm{GCM}_{\mathrm{it}-3}+\beta_{3} \mathrm{TDP}_{\mathrm{it}-3}+\beta_{4} \mathrm{TFS}_{\mathrm{it}-3}+\varepsilon_{\mathrm{it}-3}$

Analytically, this model is written as follows:

$\mathrm{OCF}_{\mathrm{it}}=-20.455-0.499 \mathrm{TDC}_{\mathrm{it}-3}+2.014 \mathrm{GCM}_{\mathrm{it}-3}+0.230 \mathrm{TDP}_{\mathrm{it}-3}-0.099 \mathrm{TFS}_{\mathrm{it}-3}$

\section{Conclusion}

In this paper, we tried to determine the ability of three different models in terms of forecasting future cash flows in the Tunisian context. Our sample included 52 Tunisian commercial companies and model estimates were made at the horizon of one, two and three years.

The first model was based on elements related to the operating cycle namely timely debt collection, gross commercial margin, timely flow of stock and timely debt payment. This model has shown effectiveness in terms of determining cash flows (Telmoudi and al. (2010)). The second model was based on the explanatory variable 
earning; this variable has already shown its deficiency in determining cash flow. Finally, the third model was based on the past operating cash flow.

The results show that the forecasting model more effective in the context of Tunisia is the one based on the timely debt collection, gross commercial margin, timely flow of stock and timely debt payment. The predictive power of this model was shown at the horizon of one year, two years and three years. These results have been approved by the appropriate statistical tests.

The past cash flows are also good predictors of future cash flows at the horizon of one, two and three years; but with a lower predictive power compared to that of the elements related to the operating cycle.

Having a very low predictive power and an insignificant coefficient estimate, earnings are not a good basis in terms of forecasting future cash flows at the horizon of one, two and three years. These results for the Tunisian context show the discrepancy between the earning and the process of generating operating cash flow.

\section{References}

AZIZ A., and LAWSON G. (1989). Cash flow reporting and financial distress model: Testing hypotheses. Financial Management Journal, p-p: 55-63.

BARTH M.E., CRAM D. P., and NELSON K.K. (2001). Accruals and the prediction of future cash flows. The Accounting Review, p-p: 27-59.

BEAVER W.H., KENNELY J.W., and VOSS W.M. (1968). Predictive ability as a criterion for the evaluation of accounting data. The Accounting Review, October, p-p: 675-683.

BEAVER W. LAMBERT R., and MORSE D. (1980). The information content of security prices. Journal of Accounting and Economics, Vol 2.

BERNARD V.L., and STOBER T.L. (1989). The nature and amount of information in cash flows and accruals. The Accounting Review, p-p: 624-652.

BOWEN R.M., BURGSTAHLER D., and DALEY L.A. (1986). Evidence on the relationships between earnings and various measures of cash flow. The Accounting Review, October.

BOWEN R.M., BURGSTAHLER D., and Daley L.A. (1987). The incremental information content of accrual versus cash flows. The Accounting Review, October, p-p: 723-747

CASEY C.J., and BARTCZAK N.J. (1985). Using operating cash flows data to predict financial distress: some extensions. Journal of Accounting Research, p-p: 384-401.

CASEY C.J., and BARTCZAK N.J. (1984). Cash flow - it's not the bottom line. Havard Business Review, July-August, p-p: 61-66.

CHARITOU A., and PANAGIOTIDES G. (1999). Financial analysis, future earnings and cash flows and the prediction of stocks returns: evidence for the UK. Accounting and Business Research, vol 29.

CHARITOU A., and VAFEAS N. (1997). The association between operating cash flows and dividend changes: an empirical investigation. Akron Business and Economic Review, January-March, p-p: 25-49.

CHRISTIE W.G., and NANDA V. (1994). Free cash flow, Shareholder value and the Undistributed Profits tax of 1936 and 1937, The Journal of Finance, XLIX, 5, p-p: 1727-1754.

DECHOW P.M. (1994). Accounting earnings and cash flows as measures of firm performance: the role of accounting accruals. Journal of Accounting and Economics, p-p: 3-42.

DECHOW P.M., KOTHARI S.P., and WATTS R.L. (1998). The relation between earnings and cash flow. Journal of Accounting and Economics, Vol.25, p-p: 133-168.

DENIS D.J, DENIS D.K., and SARIN A. (1997). Agency problems, Ownership, and corporate Diversification. Journal of Finance, LII, 1, March, p-p: 135-160

DRATINA R., and LARGAY J. (1985). Pitfalls in calculing cash flow from operations. The Accounting Review, April, p-p: 314-326.

EPSTEIN M. J., and PAVA L. (1992). How useful is the statement of cash flows?, Management Accounting, July, p-p: 52-60.

FARSHADFAR S., NG C., and BRIMBLE M. (2008). The relative ability of earnings and cash flow data in forecasting future cash flows: Some Australian evidence. Pacific Accounting Review, Vol 20 n³, pp 254-268. 
FEDHILA H. (1998). A logit model using cash flow information to predict loan delinquency. Journal of Accounting Business and Insurance.

FINANCIAL ACCOUNTING STANDARD BOARD. (1978). Objectives of financial reporting by business enterprises. Statement of Financial accounting Concepts, N1.

FINANCIAL ACCOUNTING STANDARD BOARD. (1984), Recognition and measurement in financial statement of business enterprises. Statement of financial Concepts, N5.

FINANCIAL ACCOUNTING STANDARD BOARD. (1987). Statement of cash flows. Statement of Financial accounting Standards $N^{\circ} 95$.

FINGER C.A. (1994). The ability of earnings to predict future earnings and cash flows. Journal of Accounting Research, p-p: 210-223.

GOMBOLA M.J., HASKIN, J.E., KETZ J.E., and WILLIAMS D.D. (1987). Cash flow in bankruptcy prediction. Financial Management, p-p: 55-65.

GOMBOLA M. J., and KETZ J.E. (1983), A note on cash flow and classification patterns of financial ratios. The Accounting Review, January, p-p: 105-114

GREENBERG R.R., JOHNSON G.L., and RAMESH K. (1986). Earning versus cash flows as a predictor of future cash flow measures. Journal of Accounting, Auditing and Finance, p-p: 266-277.

GUILLOUX, M. (1979). L'information comptable et la communication de l'entreprise. Revue du Financier, $\mathrm{n}^{\circ} 103-104$.

HUSSAIN S., and AL-ATTAR A. (2003). Corporate data and future cash flows. Journal of Business, Finance and Accouting.

Hurlin, L'économétrie des données de Panel (modèles linéaires simples).

JENSEN M.C. (1986). Agency Costs of free cash flow, Corporate Finance, and Takeovers. American Economic Review, 76, 2, May, p-p: 323-329

KRISHNAN G.V., and LARGAY J.A. (2000). The predictive ability for direct method cash flow information. Journal of business, Finance and Accounting, January-March, p-p: 215-245

LARGAY J.A., and STICKNEY C.P. (1980). Cash flow, Ratios Analysis and the W-T, Grant Bankruptcy. Financial Analysts Journal, July-August.

LANDRY M. (1975). Accounting concepts and their developpement modes: a critic analysis. The Chartered Account Magazine, August, p-p: 50-51.

LANG L.H.P., and LITZENBERGER R.H. (1989). Dividend Announcement, Cash Flow Signalling vs. free cash flow Hypothesis? Journal of Financial Economics, 24, p-p: 181-191

LEHN K., and POULSEN A. (1989). Free cash flow and Stockholder gains in Going Private transactions. The Journal of Finance, 44, July, p-p: 771-787

\section{LE SYSTĖME COMPTABLE DES ENTREPRISES TUNISIEN (1997).}

LIVNAT J., and ZAROWIN P. (1990). The incremental information content of cash flow components. Journal of Accounting and Economics, p-p: 25-46.

LOREK K.S., and Lee WILLINGER G. (1996). A multivariate times series prediction model for cash flow data. The Accounting Review, January, p-p: 81-101.

MC BETH K.H. (1993). Forecasting operating cash flow: evidence on the comparative abilities of net income and operating cash flow from actual cash flow data. The Mid-Atlantic Journal of Business, June, p-p: 173-187.

MILLER M., and MODIGLIANI L. (1961). Dividend policy, growth and the valuation of shares, Journal of Business, October.

MURDOCH B., and KRAUSE P. (1989). An empirical investigation of the predictive power of accrual and cash flow data in forecasting operating cash flow. Akron Business and Economic Review, p-p: 100-113

MURDOCH B., and KRAUSE P. (1990). Further evidence on the comparative ability of accounting data to predict operating cash flows. The Mid-Atlantic Journal of Business, p-p: 1-14

OHLSON J. (1990). A synthesis of security valuation theory and the role of dividends, cash flows and earnings. Contemporary Accounting Research, Spring. 
QUIRIN J.J., O'BRYAN D., WILCOX W.E., and BERRY K. T. (1999). Forecasting cash flow from operation: additional evidence. The Mid-Atlantic Journal of Business, June, p-p: 135-147.

RAYBURN J. (1986). The association of operating cash flow and accruals with security returns. Journal of Accounting Research, p-p: 112-133.

SLOAN R. (1996), Do stock prices fully reflect information in accrual and cash flows about future earnings? The accounting Review, 71.

SUBRAMANYEM K.R. (1996). The pricing of discretionary accruals. Journal of accounting and economic.

TELMOUDI A., ZIADI J., and NOUBBIGH H. (2010). Factors determining operating cash flow: case of the Tunisian commercial companies. International journal of business and management, Vol. 05, No. 05, May, p-p: $188-200$

TERNISIEN M. (1995). L'importance du concept de flux de trésorerie disponible. Revue Française de comptabilité, Mars, $\mathrm{N}^{\circ} 265$, p-p: 72-77.

WANG Z., and EICHENSEHER J. (1998). Informativness and predictability of cash flows. Journal of Applied Business Research, p-p: 21-32.

WILSON G.P. (1986). The relative information content of accruals and cash flows: combined evidence at the earnings announcement and annual report release date. Journal of Accounting Research, p-p: 165-200.

WILSON G.P. (1987). The incremental information content of accrual and funds components of earnings after controlling for earnings. The Accounting Review, p-p: 293-322.

YAICH A. (1998). L'état des flux de trésorerie. La Revue comptable et Financière, Deuxième trimestre, p-p: 9-32.

Table 1. Number of companies observed per year

\begin{tabular}{|c|c|}
\hline Year & Number of company \\
\hline 1998 & 13 \\
\hline 1999 & 15 \\
\hline 2000 & 21 \\
\hline 2001 & 40 \\
\hline 2002 & 52 \\
\hline 2003 & 52 \\
\hline 2004 & 52 \\
\hline 2005 & 52 \\
\hline 2006 & 45 \\
\hline 2007 & 45 \\
\hline 2008 & 25 \\
\hline Total & 412 observations \\
\hline
\end{tabular}

Table 2. The results of the Hausman test for the forecasting models at the horizon of one year

\begin{tabular}{|c|c|c|}
\hline Model & p-values $>\chi_{0.05}^{2}$ & Model chosen \\
\hline Model (1) & $0.4399>0.05$ & Random effect model \\
\hline Model (2) & $0.2231>0.05$ & Random effect model \\
\hline Model (3) & $0.1280>0.05$ & Random effect model \\
\hline
\end{tabular}


Table 3. The estimation results of forecasting models at the horizon of one year $(\mathrm{N}=360)$

\begin{tabular}{|c|c|c|c|c|c|c|c|}
\hline Model & $\beta_{1}$ & $\beta_{2}$ & $\beta_{3}$ & $\beta_{4}$ & $\mathrm{R}^{2}$ & $\mathrm{R}_{\text {adius. }}^{2}$ & Wald $\chi^{2}$ \\
\hline $\begin{array}{c}\text { Model } \\
(1)\end{array}$ & $\begin{array}{c}-0.512387 \\
(-6.244)^{* *}\end{array}$ & $\begin{array}{c}1.91993 \\
(5.988)^{* *}\end{array}$ & $\begin{array}{c}0.83186 \\
(5.219)^{* *}\end{array}$ & $\begin{array}{c}-0.104537 \\
(-3.878)^{* *}\end{array}$ & 0.7240 & 0.7208 & $54.28^{* *}$ \\
\hline $\begin{array}{c}\text { Model } \\
(2)\end{array}$ & $\begin{array}{c}0.453876 \\
(1.732)\end{array}$ & - & - & - & 0.1028 & 0.1002 & 2.78 \\
\hline $\begin{array}{c}\text { Model } \\
(3)\end{array}$ & $\begin{array}{c}0.653983 \\
(3.359)^{* *}\end{array}$ & - & - & - & 0.4448 & 0.4432 & $19.45^{* *}$ \\
\hline
\end{tabular}

** indicates that the $t$-statistics in parentheses, and the Wald $\chi 2$-test are significant at $1 \%$.

Table 4. The results of the Hausman test for the forecasting models at the horizon of two years

\begin{tabular}{|c|c|c|}
\hline Model & p-values $>\chi_{0.05}^{2}$ & Model chosen \\
\hline Model (1a) & $0.4011>0.05$ & Random effect model \\
\hline Model (2a) & $0.2343>0.05$ & Random effect model \\
\hline Model (3a) & $0.1876>0.05$ & Random effect model \\
\hline
\end{tabular}

Table 5. The estimation results of forecasting models at the horizon of two years $(\mathrm{N}=308)$

\begin{tabular}{|c|l|l|l|l|l|l|l|}
\hline Model & $\beta 1$ & $\beta 2$ & $\beta 3$ & $\beta 4$ & $\mathrm{R}^{2}$ & $\mathrm{R}^{2}$ adjus. & Wald $\chi 2$ \\
\hline $\begin{array}{c}\text { Model } \\
(1 \mathrm{a})\end{array}$ & $\begin{array}{l}-0.504433 \\
(-5.866)^{* *}\end{array}$ & $\begin{array}{l}1.996444 \\
(5.438)^{* *}\end{array}$ & $\begin{array}{l}0.223764 \\
(4.761)^{* *}\end{array}$ & $\begin{array}{l}-0.101453 \\
(-3.104)^{* *}\end{array}$ & 0.6022 & 0.5969 & $42.54^{* *}$ \\
\hline $\begin{array}{c}\text { Modèle } \\
(2 \mathrm{a})\end{array}$ & $\begin{array}{l}0.467887 \\
(1.115)\end{array}$ & - & - & - & 0.0626 & 0.0595 & 2.78 \\
\hline $\begin{array}{c}\text { Modèle } \\
(3 \mathrm{a})\end{array}$ & $\begin{array}{l}0.768545 \\
(3.02)^{* *}\end{array}$ & - & - & - & 0.3864 & 0.3844 & $19.45^{* *}$ \\
\hline
\end{tabular}

** indicates that the t-statistics in parentheses, and the Wald $\chi 2$-test are significant at $1 \%$.

Table 6. The results of the Hausman test for the forecasting models at the horizon of three years

\begin{tabular}{|c|c|c|}
\hline Model & $\mathrm{p}$-values $>\chi_{0.05}^{2}$ & Model chosen \\
\hline Model $(1 \mathrm{~b})$ & $0.3477>0.05$ & Random effect model \\
\hline Model (2b) & $0.2328>0.05$ & Random effect model \\
\hline Model (3b) & $0.1140>0.05$ & Random effect model \\
\hline
\end{tabular}

Table 7. The estimation results of forecasting models at the horizon of three years $(\mathrm{N}=256)$

\begin{tabular}{|l|l|l|l|l|l|l|l|}
\hline Modèle & $\beta 1$ & $\beta 2$ & $\beta 3$ & $\beta 4$ & $\mathrm{R}^{2}$ & $\mathrm{R}^{2}$ adjus. & Wald $\chi^{2}$ \\
\hline $\begin{array}{l}\text { Modèle } \\
(1 \mathrm{c})\end{array}$ & $\begin{array}{l}-0.499449 \\
(-4.623)^{* *}\end{array}$ & $\begin{array}{l}2.014365 \\
(4.118)^{* *}\end{array}$ & $\begin{array}{l}0.230665 \\
(3.403)^{* *}\end{array}$ & $\begin{array}{l}-0.099454 \\
(3.007)^{* *}\end{array}$ & 0.4622 & 0.4536 & $22.14^{* *}$ \\
\hline $\begin{array}{l}\text { Modèle } \\
(2 \mathrm{c})\end{array}$ & $\begin{array}{l}0.467887 \\
(0.243)\end{array}$ & - & - & - & 0.0364 & 0.0326 & 1.98 \\
\hline $\begin{array}{l}\text { Modèle } \\
(3 \mathrm{c})\end{array}$ & $\begin{array}{l}0.768545 \\
(2.97)^{* *}\end{array}$ & - & - & - & 0.2818 & 0.2789 & $6.46^{* *}$ \\
\hline
\end{tabular}

** indicates that the t-statistics in parentheses, and the Wald $\chi 2$-test are significant at $1 \%$. 